\title{
An Empirical Analysis of the Factors Affecting the Tax Burden of China's Banking Industry
}

\author{
Yu Zhang \\ Nanjing Normal University, Nanjing, China \\ Email: 420285541@qq.com
}

How to cite this paper: Zhang, Y. (2019) An Empirical Analysis of the Factors Affecting the Tax Burden of China's Banking Industry. Technology and Investment, 10, 31-45.

https://doi.org/10.4236/ti.2019.102002

Received: April 12, 2019

Accepted: May 28, 2019

Published: May 31, 2019

Copyright $\odot 2019$ by author(s) and Scientific Research Publishing Inc. This work is licensed under the Creative Commons Attribution International License (CC BY 4.0).

http://creativecommons.org/licenses/by/4.0/

(c) (i) Open Access

\begin{abstract}
The taxation system, as a key external factor directly related to the survival and development of the banking industry, has become the focus of theoretical research on the classification of finance and monetary. This paper takes the tax burden of the banking industry as the research object. The theoretical part combines the research status at home and abroad. Through a series of cross-country and cross-time comparative analysis, also supplemented by the mathematical model of empirical analysis, the fact that current banking industry is over-taxed comparatively has been scientifically and powerfully demonstrated. The fact is that the tax burden is relatively heavy. The empirical part focuses on the research and tests the factors that cause the tax burden and the related tax system to be biased, and from the above-mentioned influencing factors, to achieve targeted policy for the reform of China's banking tax system. At the end of this paper, policy suggestions are provided for the above conclusions.
\end{abstract}

\section{Keywords}

Banking Industry, Tax Burden, Comparative Analysis, Empirical Analysis

\section{Introduction}

In today's society, the main development trend of the banking industry has increasingly become the vane of the development of the national economy. Among the many subjective and objective factors affecting the development of the banking industry, the role of tax burden is undoubtedly crucial for the survival and development of the banking industry. It directly affects the operating income and operating costs of the economy. The existence of tax burden regulates the profit margin and creates a more fair market competition environment.

Among many subjective and objective factors, the external environmental 
factor of China's tax policy is undoubtedly crucial to the survival and development of the banking industry. It directly affects the operating cost and operating income of the economy. The existence of tax burden adjusts the profit range and creates a more fair market competition environment. The tax reform in 1994, to 2008 unification, changes to the camp in 2012, after a series of reform of our country tax system more perfect. Then the domestic scholars today think about whether our country tax revenue environment is conducive to the development and realistic problem in China's banking industry, through reducing the tax burden on Banks to increase bank performance calls for the industry is becoming more and higher. Therefore, on the premise of considering the banking industry particularity, using the theory of objective data and related analysis banking taxation burden is able to determine whether scientific and effective tax burden overweight the problem existing in Chinese banking industry, and to a certain extent, warning and specifications, including banking, many micro economic subject behaviors, improve the domestic tax system environment, to create a loose and fair market competition environment. On the basis of the above, studying the tax burden of China's banking industry and its influencing factors and conducting empirical analysis will help us determine and find the crux of the seemingly excessive tax burden of the banking industry, and help us overcome the imbalance of tax burden within the bank, unreasonable tax structure, lagging tax system and other defects. It is also conducive to the coordinated use of fiscal and monetary policies in China, and has a strong practical significance to solve the contradiction between China's current tax system and the international tax system.

In response to this topic, I have carried out a large amount of literature collation and review.

Through the search of ProQuest full-text search platform and other channels, it is found that there are few studies on the tax burden of the banking industry, and even fewer focus on the analysis of the tax burden of China's Banks. The main reason is that the situation in foreign countries is quite different from ours. From the perspective of tax system, western developed countries mainly collect the banking turnover tax in the form of value-added tax, and some even exempt from tax. Does this determine the mainstream research direction of western scholars called us to have a difference, performance in whether financial services should be taxed? Which tax model is best? Obviously, due to different national conditions, it is natural that foreign scholars focus on the development and reform of banking tax system, which is different from Chinese scholars. In the process of referring to and referring to foreign literature, this paper mainly focuses on the basic theory of taxation and the impact of taxation on banking business behavior. For example, Domar E.D's theoretical model of cost of capital, which is based on the assumption of maximizing corporate profits, is extended to the market investment behavior of various economies. This theoretical result lays a good foundation for the study of banking tax burden [1]. Another example is William (2000)'s inevitability theory of taxation. He views taxation 
from the perspective of efficiency and proposes that taxation policy should not be fixed but change with the change of the relative price of consumer goods [2].

In China, as early as 2000, some scholars have conducted preliminary research on the drawbacks of taxes and tax rates in China's banking taxation system. Up to now, the relevant theories about China's bank tax burden have become more and more mature, including not only various research methods such as comparison, normative analysis and empirical analysis, but also conclusions and suggestions are more feasible and scientific. For example, Li Wei and Tie Wei (2009), under the foundation of the previous scholars' research, creatively used empirical analysis methods to break through the framework that previous scholars were mostly limited to qualitative analysis and tax-related comparison. Based on this, they put forward policy recommendations for rationally optimizing the tax burden of the banking industry [3].

However, it is worth noting that some of these documents are qualitative analysis and simple data description. The conclusions are drawn through normative analysis and the empirical research is relatively backward. The lack of innovation in research methods and research content makes scholars mostly limited to "the routine of excessive taxation". Everything has two sides. Considering the particularity of the banking industry, there are certain reasons for its taxation system to be established. Simply asking for tax cuts and calling for tax cuts may bring unexpected harm.

Based on the collected literature, it is not hard to find that there are no more than two groups of views on the issue of whether the tax burden of China's banking industry is too heavy. Most scholars believe that: the tax burden of China's banking industry is relatively too heavy, the comprehensive tax burden is much higher than other industries; Some scholars also believe that, considering the particularity of the banking industry, the tax burden of China is not high, so we should take a more cautious attitude towards the call to reduce the tax burden of the banking industry. For example, the comparative analysis of tax burden of China's banking industry was published by Wang Min and Long Tengfei in the Journal of foreign taxation (2010.08) [4].

As early as when China was about to join the WTO, Wang Cong (2000) focused on the tax burden of China's banking industry and made a preliminary study, and also put forward a series of policy Suggestions based on China's national conditions. Later, Wang Cong made a systematic comparative analysis on the tax burden of China's banking industry in 2003, and expounded the specific impact of tax system on the tax burden of state-owned Banks [5].

This is a relatively early research idea and direction. Later, scholars found that since tax burden is the result of tax system and the core of tax policy, it may be possible to focus on the problems of excessive tax burden and unfair tax burden in China's banking industry when discussing and analyzing the tax system of China's banking industry. Such literature has emerged successively [6].

Among them, the focus of the study of tax burden by means of comparative analysis, namely domestic and foreign unfair tax burden phenomenon, is the 
most common criticism. The problem of unfair tax burden on domestic and foreign capital occurred before the merger of the two taxes, that is, before the unification of the enterprise income tax on foreign Banks. It is generally believed that China's domestic and foreign Banks adopt two different tax laws, which is against the principle of fairness. For example, He Zongyin (2002) from Shanghai university of finance and economics [7], Yin Yinpin (2003) from southwest university of finance and economics [8], Wang Cong (2003) from the research bureau of the people's bank of China [9], Wang Gang and Wu Wei (2007) from Shanghai university of finance and economics all advocated the establishment of a unified income tax system for domestic and foreign enterprises as soon as possible [10]. Driven by these documents, the enterprise income tax law of the People's Republic of China came into effect on January 1, 2008, further improving the tax environment of fair competition in China's banking industry. To sum up, till now, relevant theories on tax burden of Banks in China have become increasingly mature, including not only various research methods such as contrast, normative analysis and empirical analysis, but also distinct levels of theoretical propositions. Mainstream research contents are as follows:

First: the tax burden is too heavy, advocating to reduce the tax burden of the banking industry.

For example, Pan Yong, Yue Guining and Deng Jianping (2004) put forward some suggestions to simplify tax categories and reduce tax burden by analyzing the reasons and process of tax burden affecting the competitiveness of commercial Banks and comparing the international differences of tax burden of commercial Banks [11]. Again such as Li Wei and Tie Wei (2009) of iron in reference on the basis of existing research results, according to China's relatively heavy taxes on the impact of the banking business performance, empirical analysis, breaking the previous scholars mostly confined to the qualitative analysis and the framework of tax burden is, and accordingly puts forward reasonable optimization of banking tax policy recommendations [3].

Second: unfair tax burden, advocating uniform tax standards for domestic and foreign Banks.

Wang Dejun (2004) discussed the impact of banking tax system on banking competitiveness and robustness from the perspective of equity and efficiency Worshiping [12]. He ZongYin (2002) [6], Wang Cong (2003) [8], Yin Yipin (2003) [8], Wang Gang and Wu Wei (2007) [9], and other people think that domestic and foreign Banks in China, respectively, using two different sets of tax law, is a manifestation of the violation of fair competition principle, all claims for unifying the enterprise income tax and other tax laws, in order to create a fair competition environment, establish a unified income tax of domestic and foreign enterprises as soon as possible.

Third: the tax system is poorly designed and needs to be optimized in order to improve China's banking business performance and international competitiveness.

Such as Li Wenhong (2007) under the theory of pillar, through analysis and comparison in recent years the bank tax adjustment and the domestic and for- 
eign Banks in China tax system differences, and in recent years, China's banking sector tax changes for the measurement and calculation, can put forward by the standard normal income, interest income into bank to cancel the business tax and additional, but according to the rate of income tax rate is higher than that in general enterprises income tax, can not only guarantee the national tax revenue, and does not increase the bank tax [13].

For example, Xin Hao, Wang Tao, and Feng Pengxi (2007) et al., through empirical research on endogenous indicators that affect Banks' profitability, revealed the distorting effect of business tax and additional collection on Banks' operating performance, and strongly explained the necessity of business tax reform of commercial Banks [14].

\section{Comparative Analysis of the Tax Burden of the Banking Industry}

This paper focuses on empirical research. And in order to select the scientific and rationality of the model variables, the author first makes a comparative analysis of the following four levels of the banking tax burden, paving the way for the selection of the explanatory variables of the empirical part.

\subsection{Comparative Analysis of Tax Burdens Based on Different Industries}

At present, China has initially established a banking taxation system, which is more controversial and is undoubtedly the collection of business tax rates. Business tax is one of the main tax categories of China's banking industry. The business tax is levied according to the "financial and insurance" tax heading and the tax rate is $5 \%$.

The business tax rate statistics of various industries in China, according to the "Provisional Regulations on Business Tax", the banking industry levies a business tax rate of $5 \%$, while the transportation industry, construction industry, post and telecommunications industry or cultural and sports industry are levied at a rate of $3 \%$ (see Table 1). By contrast, the tax rate is relatively high. Taking into account the particularity of its own banking industry, debt management, high proportion of non-performing loans, serious bad debts, and excessive tax base, $5 \%$ tax burden is becoming more and more unfair.

\subsection{Comparative Analysis of Tax Types Based on Bank Types}

Not only is there a phenomenon of unfair taxation in different industries, but even within the banking industry, there will be obvious tax imbalances due to different types of banks.

The China Financial Yearbook in 2017 shows some analysis. The four major traditional banks and the top ten joint-stock banks included various business indicators such as total assets, operating income, operating expenses, business taxes and surcharges, total profits, income tax expenses and net profit. We find that the actual tax burden of the two types of banks has been alleviated and gradually 
Table 1. Statistical table of business tax rates of various industries in China.

\begin{tabular}{cc}
\hline Tax Items & Tax Rate \\
\hline Transportation Industry & $3 \%$ \\
Construction Industry & $3 \%$ \\
Finance and Insurance Industry & $5 \%$ \\
Posts and Telecommunications & $3 \%$ \\
Culture and Sports & $3 \%$ \\
Entertainment Industry & $5 \%-20 \%$ \\
Service Industry & $5 \%$ \\
Transfer of Intangible Assets & $5 \%$ \\
Selling Real Estate & $5 \%$ \\
\hline
\end{tabular}

converged in recent years. But compared with the profitability, large banks have occupied the market position of absolute advantage. The stable market share can not only bring low cost, but also create a kind of Monopoly forces hinder the market entry of other competitors. In this way, even if the profit margin of small and medium-sized banks can catch up with even larger banks, the gap in profit size is always larger.

In principle, for non-destructive fairness, the taxation of banks under the current tax system in China often needs to take into account the bank's profitability. The higher the net profit in the table, the greater the tax burden, but in today's society where the tax burdens of large and small banks are gradually merging, this trend is obviously unreasonable.

\subsection{Comparative Analysis of Banking Tax Burden Based on Time Series}

It is worth mentioning that for the comparison of the tax burden of the banking industry, many scholars in the field have provided a wide variety of methods, but the main analytical indicators are still inseparable from the two main tax categories of turnover tax and income tax. According to the data disclosed in the China Tax Yearbook, the tabulation of bank business tax and income tax since the reform of the tax-sharing system in 1994 is as follows:

In the 1994 tax reform, the corporate income tax of China's banking industry was set at $33 \%$, of which the state-owned commercial bank tax rate was 55\% (downgraded to $33 \%$ in 1997) (see Table 2).

As can be seen from the above analysis, the business tax has fluctuated slightly during this period and remained generally stable. However, there is still a defect of double taxation on the collection of business tax. The full taxation of the turnover will result in the collection of business tax on loan interest. At the same time, the value-added tax was imposed, which actually caused the double tax burden of business tax and value-added tax. It was extremely unreasonable.

Of course, compared with the 55\% income tax in 1994-1996, the problem of "tax overweight" in the banking industry has been greatly alleviated. The results of 
Table 2. List of changes in the tax rate of the banking industry since the reform of the tax-sharing system since 1994.

\begin{tabular}{ccccccc}
\hline Categories & $1994-1996$ & $1997-2000$ & 2001 & 2002 & $2003-2007$ & 2008 -now \\
\hline $\begin{array}{c}\text { business tax } \\
\text { corporate } \\
\text { income tax }\end{array}$ & $5 \%$ & $8 \%$ & $7 \%$ & $6 \%$ & $5 \%$ & $5 \%$ \\
\hline
\end{tabular}

this longitudinal analysis at least indicates that China's tax reform is constantly moving to adapt to the needs of the development of modern market economy.

\subsection{Comparative Analysis of Tax Burdens Based on Country-Specific Banking}

Since China joined the WTO in 2001 and the country has opened to the world, both academic theorists and political rulers have tended to learn from international practices on the basis of respecting China's national conditions and take the essence to abandon its dross. Of course, this applies equally to the reform of the banking tax system in China.

A comparative analysis of the tax burdens of different countries' banking industry is now carried out, and the data and data obtained are compiled as shown in the following table.

The analysis shows that after the adjustment of the tax rate in 2008, China's banking industry and other countries do not have much difference in income tax collection. It is worth noting that the turnover tax (see Table 3).

Developed countries generally implement a tax exemption or low tax policy for turnover tax (especially business tax). The $5 \%$ tax rate in China seems to be very unreasonable, far higher than several major developed countries. In this way, coupled with the $25 \%$ corporate income tax, the comprehensive tax rate of China's banking industry can be said to be on the high side. If we take our country's broader tax base into account (including some generations that are not included in bank income), it is not unreasonable to say that the actual tax burden is too heavy in China's banking industry.

\section{An Empirical Analysis of the Factors Affecting the Tax Burden of China's Banking Industry}

After the above-mentioned series of analysis, a basic point was initially determined: even after many adjustments since the reform and opening up, China's banking tax system has become closer to standardization and rationalization, but it still cannot conceal the fact that the current banking industry is heavily biased.

The main influencing factors of this fact, from the results of comparative analysis, can be summarized as follows:

1) Tax-based design flaws: linked to total assets, return on assets, etc.

2) Double taxation issues: linked to the collection of business taxes.

3) Innate vulnerability of banks: linked to credit prevention capacity indicators such as non-performing loans. 
Table 3. Different countries implement regulations for banking taxation.

\begin{tabular}{|c|c|c|}
\hline Country & Income tax & Turnover tax \\
\hline America & $\begin{array}{l}\text { progressive tax rate in excess of specific } \\
\text { amount: } 35 \%\end{array}$ & - \\
\hline Japan & $\begin{array}{l}\text { Small Banks with less than } 100 \text { million } \\
\text { yen in capital: } 28 \% \text {; Banks above } 100 \\
\text { million yen: } 37.5 \%\end{array}$ & $5 \%$ consumption tax \\
\hline Germany & $\begin{array}{l}\text { distribute earnings: } 32 \% \\
\text { undistributed earnings: } 48 \%\end{array}$ & The state levies a $5 \%$ sales tax on profits. \\
\hline England & $\begin{array}{l}\text { progressive tax rate in excess of specific } \\
\text { amount: } 25 \%-33 \%\end{array}$ & - \\
\hline France & $\begin{array}{l}\text { Short-term income tax rate: } 36.6 \% \\
\text { Long-term income tax rate: } 20.9 \%\end{array}$ & - \\
\hline Italy & composite tax rate: $53.2 \%$ & - \\
\hline Canada & $4 \%-17 \%$ & - \\
\hline China & $33 \%-25 \%$ & $\begin{array}{l}\text { Local currency credit is subject to business tax } \\
\text { of } 5 \% \text { of interest income }\end{array}$ \\
\hline
\end{tabular}

4) Lag of the tax system: Whether the bank's profitability, solvency indicators and risk prevention ability indicators match.

The theoretical and practical achievements of the classics of predecessors and scholars are not repeated here. The highlight of this paper is to give up the usual ideas and ideas of repeated evidence, but to study the root causes and to find out which factors need to be responsible for this problem and which factor is insignificant?

We focus on the key words of influencing factors of excessive tax burden with collecting data and setting up models. And finally, we conduct an empirical analysis combining qualitative and quantitative analysis with the Industrial and Commercial Bank of China as a typical representative.

\subsection{Sample and Variable Selection}

After reviewing the various literature and comparing the tax burden differences of various countries in various periods, we start from the comparative analysis of the influencing factors. The indicators of the typical representativeness of the following banks are preliminarily determined, which are also linked to the bank tax burden level. The important variables describe the size of the bank, profitability, solvency and asset quality.

The explanatory variable: Effective Tax Rate (ETR).

It is the actual tax rate of the bank which is taken from the annual report of the Industrial and Commercial Bank of China, and it is different from the nominal tax rate.

\subsection{Some Consi}

Considering the availability and computability of data, this paper selects the time series data of the bank from 2000 to 2017, including the total assets, with one of 
the four representative traditional banks, Industrial and Commercial Bank of China. A series of data including asset yields, non-performing loan ratios, capital cost ratios and actual tax rates (see Table 4).

The data processing software used in this paper is: Eviews 9.

\subsection{Model Setting}

We using the multiple regression analysis method in order to eliminate the possible heteroscedasticity of the variables, logarithmically treat all the variables, and construct the OLS model as follows:

$$
\begin{aligned}
E T R_{i t}= & \beta_{0}+\beta_{1} T A_{i t}+\beta_{2} R O E_{i t}+\beta_{3} N L R_{i t}+\beta_{4} C I R_{i t} \\
& +\beta_{5} C A R_{i} t+\beta_{6} I T R_{i t}+\beta_{7} B T R_{i t}+\varepsilon_{i t}
\end{aligned}
$$

Among them: $E T R$-actual tax negative rate; $\beta_{0}$-constant term; $\beta_{i}$-parameter of the $i$-th explanatory variable; $T A$-total assets; $R O A$-return on assets; $N L R$-non-performing loan ratio; $C I R$-Cost-income ratio; $C A R$-capital adequacy ratio; $I T R$-income tax rate; $B T R$-business tax rate; $\varepsilon$-random error term, used to describe the interference of the model not reflected in the model.

\subsection{Empirical Test and Results}

\subsubsection{Estimation of Multiple Regression Parameters Using OLS}

(Eviews results are organized as follows:)

Analysis (see Table 5):

1) Goodness of fit

In the multiple linear regression model, the adjusted R2 value is closer to 1 , indicating that the regression line fits the observations better; otherwise, the worse. According to the relevant data in the above table, the adjusted-R2 is 0.985901, which indicates that the model has a high degree of fit to the sample.

2) Significance of partial regression coefficient [T test]

Let $\mathrm{H}_{0}: \beta_{0}=\beta_{1}=\beta_{2}=\beta_{3}=\beta_{4}=\beta_{5}=\beta_{6}=\beta_{7}=0$.

$\mathrm{H}_{1}: \beta_{0}, \beta_{1}, \beta_{2}, \beta_{3}, \beta_{4}, \beta_{5}, \beta_{6}, \beta_{7}$ are not all 0 .

Given the significance level $\alpha=0.05$, the t statistic of C, CAR, ITR, and BTR are all greater than the given significance level, reject the null hypothesis, accept the alternative hypothesis, and explain the capital adequacy ratio, income tax rate, and business tax rate to the actual tax rate. There is a significant impact, while other variables have no significant effect on the actual tax rate.

The t-test is not significant, but the model can be determined with a high coefficient, that is, the significance of the model is inconsistent with the significance of the variable, indicating that there may be multiple collinearity.

3) Significance of regression model [F test]

Given the significance level $\alpha=0.05$, the degree of freedom is found to be $\mathrm{k}-1$ $=6$ in the $\mathrm{F}$ distribution table, and the critical value $\mathrm{F} \alpha(6,8)=3.58$ of $\mathrm{n}-\mathrm{k}-1=$ 8. The $\mathrm{F}=140.8563$ obtained by the OLS distribution table is larger than the critical value $\mathrm{F} \alpha(6,8)$, so rejecting the null hypothesis and accepting the alternative hypothesis, indicating that the regression equation is significant, the combi- 
Table 4. Selection of explanatory variables.

\begin{tabular}{|c|c|c|}
\hline Total asset & TA & Measure the size of the bank; \\
\hline Return on assets & $\mathrm{ROA}$ & $\begin{array}{l}\text { The percentage of net profit after tax and total assets } \\
\text { which reflects the bank's profitability; }\end{array}$ \\
\hline Non-performing loan ratio & NLR & $\begin{array}{l}\text { The ratio of non-performing assets to total loan balances, } \\
\text { which measures the credit risk prevention ability of } \\
\text { commercial banks; }\end{array}$ \\
\hline Capital adequacy ratio & CAR & $\begin{array}{l}\text { The ratio of the bank's total capital to its risk-weighted } \\
\text { assets, an indicator of the bank's solvency }\end{array}$ \\
\hline Cost-Income Ratio & CIR & $\begin{array}{l}\text { Bank operating expenses plus the ratio of depreciation to } \\
\text { operating income }\end{array}$ \\
\hline Income tax rate & ITR & The ratio of bank income tax expenses to pre-tax profits \\
\hline Business tax rate & BTR & $\begin{array}{l}\text { The ratio of bank business tax and surcharge to pre-tax } \\
\text { profit is selected as one of the variable indicators for ease } \\
\text { of calculation }\end{array}$ \\
\hline
\end{tabular}

Table 5. OLS estimation model regression results.

\begin{tabular}{cccccc}
\hline & Expected symbol & $\begin{array}{c}\text { Estimate of } \\
\text { parameter }\end{array}$ & $\begin{array}{c}\text { Parameter standard } \\
\text { deviation }\end{array}$ & T-statistic & P-value \\
\hline CA & & 0.769278 & 0.288733 & 2.664322 & 0.0323 \\
TA & uncertain & $-1.13 \mathrm{E}-10$ & $1.97 \mathrm{E}-09$ & -0.057286 & 0.9559 \\
$\mathrm{ROA}$ & - & -0.12637 & 0.054678 & $-2.31108^{*}$ & 0.0541 \\
$\mathrm{CIR}$ & - & -0.00826 & 0.005686 & -1.451891 & 0.1898 \\
$\mathrm{NLR}$ & - & 0.005125 & 0.002949 & 1.738059 & 0.1258 \\
$\mathrm{CAR}$ & - & -0.01539 & 0.006123 & $-2.513047^{* *}$ & 0.0402 \\
$\mathrm{ITR}$ & - & 0.585089 & 0.082656 & $7.078604^{* * *}$ & 0.0002 \\
$\mathrm{BTR}$ & - & 0.16958 & 0.01633 & $10.38453^{* * *}$ & 0.0000 \\
\hline
\end{tabular}

Note: ${ }^{\star}$ indicates a $10 \%$ significance level, ${ }^{* *}$ indicates a $5 \%$ significance level, and ${ }^{* *}$ indicates a $1 \%$ significance level. Among them: ETR-actual tax negative rate; $\beta_{0}$-constant term; $\beta_{i}$-parameter of the $i$-th explanatory variable; $T A$-total assets; $R O A$-return on assets; $N L R$-non-performing loan ratio; $C I R$-Cost-income ratio; $C A R$ - capital adequacy ratio; ITR —income tax rate; $B T R$-business tax rate; $\mathcal{E}$-random error term, used to describe the interference of the model not reflected in the model.

nation of the seven variables does have a significant impact on the inflation phenomenon.

\subsubsection{Empirical Test}

1) Multicollinearity test

It can be seen from the correlation coefficient table of each explanatory variable that the coefficients of the partial variables are more than $80 \%$, and some even as high as $96 \%$, such as NLR and CIR.

It can be seen that there is a certain multicollinearity between the explanatory variables, and although the linear regression fit of the equation is good, the parameter $t$ values of CIR, NLR, TA and other variables are not significant; in addition, some explanatory variable coefficient symbols and The economic signi- 
ficance does not match, indicating that the model has multiple collinearity.

[Solutions].

First delete the variable TA that causes multi-collinearity, and the inconspicuous CIR and NLR are organized:

At this time, the P-value of each variable in the model is less than 0.05 , indicating that the variable is significant (see Table 6). After passing the T-test, and the adjusted R2 is 0.985820 , the overall fit of the model is good, so the parameters are brought into the model:

$$
\begin{aligned}
E T R_{i t}= & -0.418717-0.056728 R O A_{i t}-0.013263 C A R_{i t} \\
& +0.548108 I T R_{i t}+0.162794 B T R_{i t}+\varepsilon_{i t}
\end{aligned}
$$

At this point, both the variables and the model are significant, but the DW value (1.487923) deviates significantly from the 2 , indicating that there is an autocorrelation problem.

2) Heteroscedasticity test

The white test was performed on the model

$E T R_{i t}=\beta_{0}+\beta_{1} R O A_{i t}+\beta_{2} C A R_{i t}+\beta_{3} I T R_{i t}+\beta_{4} B T R_{i t}+\varepsilon_{i t}$ using E-views software.

Analysis: Given a significance level of $5 \%$, the $\mathrm{Obs}^{\star} \mathrm{R}$-squared value from the above table is 1.801671 , and the corresponding p-value is 0.7722 , which is greater than 0.05 indicating that there is no heteroscedasticity (see Table 7).

3) Autocorrelation test and correction

In the Eviews software, the second-order autoregressive of the random interference term is entered, that is, enter "ls etr c roa car itrbtrar (1) or (2)" in the dialog box, and the result is organized.

At this time, the DW value is 2.197643 , which is close to 2 , so there is no autocorrelation after the correction, and the modified model and variables are significant (see Table 8).

Then the factor is:

\begin{tabular}{|c|c|c|c|c|}
\hline \multicolumn{5}{|c|}{ Panel A } \\
\hline Variable & Estimation & Standard deviation & T-statistic & $\mathrm{P}$-value \\
\hline $\mathrm{C}$ & 0.418717 & 0.041102 & $10.18732^{\star * *}$ & 0.0000 \\
\hline $\mathrm{ROA}$ & -0.056728 & 0.013475 & $-4.209726^{\star * *}$ & 0.0018 \\
\hline CAR & -0.013263 & 0.002969 & $-4.46744^{\star * *}$ & 0,0012 \\
\hline ITR & 0.548108 & 0.064782 & $8.460772^{\star * \star}$ & 0.0000 \\
\hline BTR & 0.162794 & 0.014107 & $11.53996^{\star * *}$ & 0.0000 \\
\hline \multicolumn{5}{|c|}{ Panel B } \\
\hline & $\mathrm{R} 2$ & & \multicolumn{2}{|c|}{0.989872} \\
\hline & Adjust-R2 & & \multicolumn{2}{|c|}{0.98582} \\
\hline & D-W & & \multicolumn{2}{|c|}{1.487923} \\
\hline
\end{tabular}

Table 6. Modified model regression results.

Note: Among them: $E T R$ - actual tax negative rate; $\beta_{0}$-constant term; $\beta_{i}$-parameter of the $i$-th explanatory variable; $T A$-total assets; $R O A$-return on assets; $N L R$-non-performing loan ratio; $C I R$-Cost-income ratio; $C A R$ - capital adequacy ratio; $I T R$-income tax rate; $B T R$-business tax rate; $\varepsilon$-random error term, used to describe the interference of the model not reflected in the model. 
Table 7. White test.

\begin{tabular}{cccc}
\hline F-statistic & 0.341269 & Prob. F $(4,10)$ & 0.8441 \\
\hline Obs $^{*}$ R-squared & 1.801671 & Prob. Chi-Square (4) & 0.7722 \\
Scaled explained SS & 0.459997 & Prob. Chi-Square (4) & 0.9773 \\
\hline
\end{tabular}

Table 8. Final model regression results.

\begin{tabular}{ccccc}
\hline Variable & Estimation & Standard deviation & T-statistic & P-value \\
\hline ROA & -0.040084 & 0.006847 & $-5.85393^{* * *}$ & 0.0011 \\
CAR & -0.000495 & 0.001883 & $-0.263166^{* * *}$ & 0.0012 \\
ITR & 0.610481 & 0.056074 & $10.88698^{* * *}$ & 0.0000 \\
BTR & 0.172612 & 0.007437 & $23.20968^{* * *}$ & 0.0000 \\
AR (1) & 1.267237 & 0.103526 & $12.24079^{* * *}$ & 0.0000 \\
AR (2) & -0.482332 & 0.104487 & $-4.616179^{* * *}$ & 0.0036 \\
R^2 & 0.998768 & & - & - \\
Adjust-R^2 & 0.997535 & & - & - \\
F-stat & 810.5204 & - & - & 0.000 \\
D-W & 2.197643 & - & - & - \\
\hline
\end{tabular}

Note: Among them: $E T R$-actual tax negative rate; $\beta_{0}$-constant term; $\beta_{i}-$ parameter of the $i$-th explanatory variable; $T A-$ total assets; $R O A$-return on assets; $N L R$-non-performing loan ratio; CIR-Cost-income ratio; $C A R$ - capital adequacy ratio; $I T R$-income tax rate; $B T R$-business tax rate; $\varepsilon$-random error term, used to describe the interference of the model not reflected in the model.

$$
\begin{aligned}
\operatorname{ETR}_{i t}= & 0.215124-0.040084 R O A_{i t}-0.000495 C A R_{i t}+0.610481 I T R_{i t} \\
& +0.172612 B T R_{i t}+1.267237 \operatorname{ar}(1)-0.482332 \operatorname{ar}(2)+\varepsilon_{i t}
\end{aligned}
$$

That is, the final result of the model.

\section{Conclusions and Recommendations}

\subsection{Conclusion}

After a series of comparative analysis and empirical research, we believe that China's banking tax burden is indeed too heavy, not to cater to the mainstream view, the argument is conclusive, and has sufficient persuasive data support. It should be emphasized that although there are problems that cannot be ignored in China's tax system, we should still maintain an optimistic attitude.

1) China's banking tax burden is indeed relatively heavy.

Through the comparative analysis of domestic and foreign bank tax rates, this paper focuses on the distortion effect of business tax, and combines the internal and foreign tax inequality and double tax burden that existed after the founding of the People's Republic of China, as well as the current excessive rate and unreasonable tax base. And the analysis has also confirmed the fact that China's banking industry's comprehensive tax burden is relatively heavy.

In the second part of this paper, quantitative and qualitative methods are used to supplement and analyze the differences in tax rates between different types of 
industries and banks of different natures. With the support of specific data, the above propositions are further demonstrated.

2) Tax-based design flaws, repeated taxation problems, the inherent vulnerability of banks and the lag of taxation system are the main factors that cause the tax burden of banks in China to be relatively heavy. At the macro level, the ruling party can adjust the relevant policies and regulations to create a more fair and reasonable, competitive domestic tax environment.

3) The bank itself can alleviate the tax burden by optimizing the return on assets, the capital adequacy ratio, and reasonable tax avoidance.

The empirical research shows that the ROA of the return on assets and the ROA of the capital adequacy ratio is negatively correlated with the actual tax rate of the bank. The turnover tax rate and the income tax rate are in the same direction as the actual tax rate. Therefore, in order to reduce the relatively excessive tax burden of the banking industry, it is necessary to adjust the bank's own asset return rate and capital adequacy ratio, and cooperate with the state tax policy to avoid tax in a short period of time in order to be in a more favorable position in the competition.

\subsection{Suggestions on China's Banking Tax System Reform}

\subsubsection{Revolving Tax Reform}

From the above comparative analysis, there are many shortcomings in the current turnover tax of China's banking industry, which is not conducive to fair competition and healthy development under the open economy. In particular, business tax and surcharges, compared with domestic and foreign comparisons, China's business tax is as high as $5 \%$ and various education taxes and urban construction taxes are attached, which is extremely unreasonable.

Based on this, we propose the following specific measures on the reform of the turnover tax:

1) Adjust the tax rate of excessive business tax and the unreasonable tax base, and gradually cancel the two additional taxes. Policy reform and improvement of China's current tax system, determine scientific and reasonable turnover tax rate, tax base and taxation methods, distinguish between taxable items and tax-free items, and consider the blank part of the current tax system (such as taxation of financial derivatives) Take differential taxation.

2) Gradually promote the pilot reform of the banking industry, and learn from the historical experience of some successful pilot industries to complete the reasonable transition of business tax to value-added tax. At the same time, pay attention to perfecting the invoice management system. Only by eliminating the problem of double taxation can we reduce the risk of tax payment and taxation of banks, and it is more conducive to improving the financial management level of the banking industry.

3) The turnover tax offsets the loss strategy. When the bank's operating losses reach a warning value, part of the current turnover tax is allowed to offset the loss. 


\subsubsection{Income Tax Reform}

1) Reforming bad debts and bad debt withdrawal reserves.

In the process of lending, banks inevitably have a high non-performing loan ratio, and a large part of them come from the state financial compulsory distribution. Drawing on the experience of developed countries, China should establish and strengthen the identification method of bank loan losses. Only through the dual supervision and cooperation of the banking regulatory department and the fiscal and taxation department can we effectively give a tax break in the true sense of reasonableness and reasonableness for the part of the loan that exceeds the special reserve. This will not only help to write off and supervise the bank's bad debts, loan losses, but also reduce the bank's operational risks.

2) Increase the scope of pre-tax deduction of income tax.

The current deduction of wages from the taxable wage system to the ergonomics system has broken the limitation of linking wages to people, and more effectively motivated employees to exert his value. In addition, if the banking industry is allowed in difficult times the provision for full provision before the tax can also alleviate the unreasonable tax burden to some extent.

3) It is recommended to appropriately reduce the tertiary income tax of $15 \%$, $20 \%$ and $25 \%$ of the bank income tax rate. Firstly, the nominal burden of corporate income tax should be appropriately reduced. Secondly, the international corporate income tax rate should be generally reduced.

\subsubsection{Others}

1) Encourage the development of small and medium-sized banks, and issue tax incentives to improve the return on assets and capital adequacy of the banking industry, and improve the performance of the business while reducing the actual tax burden. The state needs to truly pay attention to the particularity of the bank's high debt management, and assumes this responsibility for this part of the non-performing assets, and supports and encourages the development of the banking industry.

2) Strengthen tax collection and management. When reducing the tax burden of the banking industry, tax collection and management should be strengthened, and tax losses must be strictly prevented. This can not only compensate for the loss of fiscal revenue caused by tax cuts, but also regulate the tax system, maintain the authority of the tax law, and facilitate the fair competition between banks. It should be noted that in particular, it is necessary to improve the tax system vacancies in financial derivatives and strictly manage them.

3) Those in power should widely listen to the opinions of professionals in the industry and adjust the tax policy to improve the tax environment of the domestic banking industry.

\section{Conflicts of Interest}

The authors declare no conflicts of interest regarding the publication of this paper. 


\section{References}

[1] Domar, E.D. and Musgrave, A. (1994) Proportional Income Taxation and Risk-Taking Quarter. Journal of Economics, 83, 263-283.

[2] William, J. (2000) The Treatment of Financial Services Consumption Tax. National Tax Journal, 53, 841-852. https://doi.org/10.17310/ntj.2000.4.03

[3] Li, W. and Tie, W. (2009) Comparative Taxation, Performance Impact and Countermeasures of China's Banking Industry. Financial \& Finance, No. 4, 7-10.

[4] Wang, M. and Long, T.F. (2010) Comparative Analysis of Tax Burden in China's Banking Industry. Foreign Taxation, No. 8, 22-25.

[5] Wang, C. (2000) Research on Tax Burden of China's Banking Industry. Financial Research, No. 2, 62-70.

[6] Song, W. (2009) Banking Tax System Improvement and Discussion. Financial Economics, No. 1, 112-114.

[7] He, Z.Y. (2002) China's Financial Tax Reform after China's Accession to the WTO. Foreign Taxation, No. 3, 66-72.

[8] Yin, Y.P. and Yang, F. (2011) Comparison and Thinking of Tax Defect Level of Listed Financial Enterprises. Shanghai Finance, No. 5, 103-107.

[9] Wang, C. (2003) Financial Tax System and State Commercial Bank Tax (Part 1). Wuhan Finance, No. 8, 8-13.

[10] Wang, G. and Wu, W. (2007) A Comparative Analysis of the Tax Treatment of Domestic and Foreign Banks after Joining the WTO Transition Period. International Taxation, No. 3, 10-14.

[11] Pan, Y., Gui, N. and Deng, J.P. (2004) On the Influence of Tax Burden on the International Competitiveness of Commercial Banks. Guangxi Financial Research, No. 10, 49-51.

[12] Wang, D.J. (2004) Fairness and Efficiency of China’s Banking Tax System. Tax Research, No. 7, 32-34.

[13] Li, W.H. and Zhao, R.X. (2011) Research on the Relationship between Tax Burden and Business Performance of Chinese Commercial Banks. Economic Research Guide, No. 13.

[14] Xin, H., Wang, T. and Feng, P.X. (2007) International Comparison and Empirical Research on the Impact of Commercial Bank Tax System. International Finance Research, No. 12, 37-44. 